\title{
Beszámoló \\ a XXXIV. Országos Tudományos Diákköri \\ Konferencia Humán Tudományi Szekciójának \\ Fordítástudományi Tagozatáról
}

(ELTE BTK 2019. április 25.)

\author{
Sohár Anikó \\ E-mail:sohar.aniko@btk.ppke.hu \\ Érsek Csenge \\ E-mail:ersekcsenge@gmail.com \\ Sánta Lúcia \\ E-mail:lucia6277@gmail.com \\ Rudolf Anna \\ E-mail: rudolfanna@gmail.com
}

2019. április 25-én az Eötvös Loránd Tudományegyetem Bölcsészettudományi Karán került sor a XXXIV. OTDK Fordítástudományi Tagozatára, amelynek során reggel kilenctől délután ötig hangzott el az előzetes bírálatok alapján erre érdemesnek ítélt 11 előadás. A zsürit Horváth Ildikó (ELTE), Bozsik Gyöngyvér (PPKE) és Lesznyák Márta (SZTE) alkotta, akik alapos, szakszerü megjegyzésekkel füszerezték értékelésüket, s tanácsokkal látták el az indulókat, hogyan tehetnék kutatásukat még jobbá. A házigazdán kívül a Sapientia Erdélyi Magyar Egyetemet képviselte három, a Miskolci Egyetemet kettő, míg a pozsonyi Comenius Egyetemet és a Pázmányt egy-egy hallgató: rendkívül örvendetes, hogy a fordítástudományi tagozat már nem csak itthoni diákokat vonz. A témák igen változatosak voltak a gépi fordítástól a borászati és pirotechnikai szakszövegeken át a képregények vizsgálatáig, de leginkább az irodalmi müvek átültetése, a müfordítás különféle kérdései domináltak, s azokból is a populáris műfajok. Az előadások közül három angol nyelven hangzott el. Az első három

Hivatkozás: Sohár A., Érsek Cs., Sánta L. Rudolf A. 2019. Beszámoló a XXXIV. Országos Tudományos Diákköri Konferencia Humán Tudományi Szekciójának Fordítástudományi Tagozatáról (ELTE BTK 2019. április 25.) Fordítástudomány 21. évf. 2. szám. 115-121. DOI: https://doi.org/10.35924/fordtud.21.2.10 
helyezett kutatása és előadása kiemelkedett a mezőnyből, ahogy azt az alábbi, kérésemre a vizsgaidőszak kellős közepén megírt összefoglalók is kellőképpen szemléltetik:

\title{
1. helyezett
}

\section{Longitudinális esettanulmány fordító szakos hallgatók részvételével: a fordítói stratégiák vizsgálata folyamatorientált megközelítésben}

\author{
Érsek Csenge \\ (ELTE, Forditó és tolmács MA)
}

Témavezető: Károly Krisztina (ELTE, egyetemi tanár)

Kutatásom a fordítástudomány területén végeztem, azon belül a fordítás folyamatát vizsgáltam a fordítói stratégiákra fókuszálva. A kutatás célja a mesterszintű fordítóképzésben résztvevő hallgatók fordítói stratégiáinak vizsgálata volt: a stratégiák azonosítása és leírása, az egyes hallgatók eseteinek összehasonlítása, valamint annak feltárása, hogy az alkalmazott stratégiáik változnak-e a képzésük során, és ha igen, hogyan. A stratégia fogalmát Séguinot (1991) alapján igen tágan, a következőképpen értelmezem: stratégiák „mind a tudatos és ösztönös eljárások, mind a szemmel látható müveletek és mentális folyamatok”, amelyek a fordítás folyamat során végbemennek (p. 82). Ezen fordítói stratégiák kutatása a szélesebb fordítói kompetencia elméleti keretén belül - amelyet többek között a PACTE kutatócsoport modellezett (lásd Hurtado Albir, 2017) - a stratégiai alkompetencia pontosabb megértéséhez járulhat hozzá.

A kutatást egy kvalitatív esettanulmány keretében valósítottam meg, amelyben egy képernyőfelvevő szoftvert valamint a retrospektív és az egyidejü hangosan gondolkodás technikáját alkalmaztam a fordítói stratégiák megismerésére. Ezekkel az eszközökkel lehetőség nyílik bepillantást nyerni a hallgatók gondolatvilágába a fordítás során. A kutatás négy adatfelvételből állt: a kétéves képzés minden félévében végeztem egyet, először 4-4, majd 3-3 magyar és finn hallgató részvételével annak érdekében, hogy a magyar helyzet mellett a nemzetközi viszonylatokra is reflektáljon a kutatás. A finn fordítóképzés és fordításkutatás igen elismert a világban, ezért szolgál jó összehasonlítási alapul. Az adatfelvételek alkalmával a következő müfajú szövegekből fordítottak részleteket a hallgatók (az adatfelvételek sorrendjében): szépirodalmi elbeszélő szöveg, ismeretterjesztő újságcikk, publicisztikai elbeszélő szöveg valamint jogi szakszöveg.

Mivel változatos múfajú és stílusú szövegekkel dolgoztak a diákok, sokféle fordítási stratégiát lehetett azonosítani a vizsgálatban. Ezek egy része illeszkedik Séguinot (1996), Krings (1986), valamint Gerloff (1986) korábbi kategóriáihoz, de van közöttük olyan is, amelyeket jelen kutatás tárt fel elsőként. A fordítási stratégiák szempontjából további fontos új eredmények is születtek. A hallgatók stratégiái változtak az adatfelvételek során: ellenörzési stratégiájuk például 
az utolsó két adatfelvételre egységesedett, egynyelvü és kétnyelvü ellenőrzést is végeztek. Keresési és kutatási stratégiáik is módosultak: a 2. és 3. adatfelvétel során komplexebbek lettek, többlépcsőssé váltak (a komplexitás mértéke egyénenként különbözött), a 4. adatfelvétel alkalmával pedig megfigyelhető volt, hogy a hallgatók egyik fele részletes háttérkutatást végzett szakmai felületeken a szakterminusok értelmezése közben, másik fele többször hagyatkozott az intuíciójára, az ún. belsö keresésre. Alkalmazkodási stratégiáik a következőképpen alakultak: a 3. és 4. adatfelvételre a célközönség vélt igényeihez való alkalmazkodás, a pontosság és a szöveg funkciójának megtartása vált dominánssá a korábbi „magyaros”, „finnes” fordítás elérése helyett. A fordítóképzések szempontjából pedig érdekes eredmény, hogy a 2., 3. és 4 . adatfelvételkor a hallgatók már utaltak a képzésen tanultakra is.

Összegzésül elmondható, hogy a hallgatói stratégiák részletes leírása a fordítói kompetencia alaposabb megértéséhez is hozzájárul. A kutatás közvetlen gyakorlati haszna pedig abban rejlik, hogy bepillantást nyerünk a hallgatók sajátos gondolatvilágába fordítás közben, ami hasznos információkkal szolgál a fordítóképzések számára. Bár az egyéni különbségek és a kis minta miatt általánosítható következtetéseket nem lehet levonni az eredményekből a képzésen belüli fejlődésről, a szakirodalom eddigi eredményeit is figyelembe véve azt lehet feltételezni, hogy az azonosított változásokkal a hallgatók fordítási gyakorlata a 3. és 4. adatfelvételkor a félhivatásos és hivatásos fordítók gyakorlatához közelített. A kutatás újszerüsége nem csupán a vizsgált témában rejlik, hanem a kutatás módszerében is (a fordítói stratégiák feltáró vizsgálata longitudinális megközelítéssel), hiszen nemzetközi szinten is kevés kutatást végeztek ilyen jellemzőkkel, Magyarországon pedig kifejezetten hiánypótló kutatásnak minősül.

\title{
2. helyezett
}

\section{A paradigmaváltás lehetősége a gyermekirodalom fordításában}

\author{
Sánta Lúcia \\ (PPKE, Forditó és tolmács $M A$ ) \\ Témavezető: Somló Ágnes (PPKE, egyetemi adjunktus)
}

Kutatásom a gyermekirodalom elidegenítő fordításának rövidtávú hatásait vizsgálja. A magyar hagyományt ugyanis a honosítás jellemzi, noha a szakirodalomban egyáltalán nincs egyetértés azt illetően, hogy melyik az előnyösebb. Ennek egyik oka alighanem az, hogy nemzetközi szinten is kevés empirikus kutatás vizsgálja a stratégiák gyermekekre gyakorolt hatását. Dolgozatom ezt a hiányt hivatott pótolni, egy mindeddig elhanyagolt, fiatal korosztályra, a 4-6 éves mesehallgatókra fókuszálva, fejlődéspszichológiai szempontok bevonásával.

Abból az alapfelvetésből indultam ki, hogy a hagyományosan alkalmazott, erős honosításban elvész a világ sokszínüsége, ezáltal új benyomásoktól és is- 
meretektől fosztja meg a gyermekeket - így azonban az idegen elemek idősebb korukban is nehézséget okozhatnak nekik, amelyet Yamazaki egy ördögi körnek nevez (2002: 58). A jelenlegi kutatás még alacsony elemszámmal dolgozik, így következtetései egyelőre csak iránymutatóak, további kutatások, módszertani finomítások és mindenekelőtt jóval nagyobb és változatosabb minta szükséges ahhoz, hogy határozott következtetéseket vonhassunk le.

A kutatáshoz egy Kenyában játszódó mese két fordítását készítettem el, az egyik honosító stratégiával készült, a hazánkban hagyományos magyarosító és neutralizáló eszközökkel, míg a második a kurrens fordítói trendhez képest elidegenítő, azaz sokkal többet őriz meg a forráskultúrából. Utóbbi megközelítés szakirodalmi alapját Klingberg szövegkörnyezeti adaptációs modelljére alapoztam (idézi Telci és Çoban 2017: 39), illetve azon megállapítására, hogy gyermekeknek íródott könyveket a lehető leghűségesebben kell lefordítani, hiszen a szerzőtől elvárható, hogy a gyermekek számára megfelelő szöveget hozott létre (idézi Puurtinen 2006: 59).

A fordításokat három óvodában olvastam fel, kisebb csoportokban, összesen harmincegy gyermeknek, majd egyenként interjút készítettem velük, illetve egy rajz készítésére kértem őket az egyik kultúraspecifikus elemről, a mesében szereplő nagy fáról / majomkenyérfáról. Ez utóbbi egy új elemet, a belső képek reprezentációját vizsgálja, míg a további szempontok a korábbi kutatásokhoz hasonlóan (Cámara-Aguilera és Faber 2015), az alábbiak: motiváció, megítélés, megértés és felidézés.

A kutatás eredményei szinte teljesen megegyező motivációt és megértést mutatnak a két megközelítésnél. A megítélésben, pontosabban a szereplők megítélésében adódtak különbségek, ezek összefüggésben állhatnak az életkorral - a különbség a fiatal korosztálynál jóval kisebb volt -, az egocentrizmussal, illetve a nevek ismeretlenségével. A rajzokból látszik, hogy az elidegenítés erősebb hatást gyakorolt a gyermekek fantáziájára, többször megjelentek a kenyeret termő fák. A felidézés tekintetében, a várakozásoknak megfelelően, a honosító fordítást hallgatók szerepeltek jobban, az elidegenítés azonban nagyobb fegyelmezettséget váltott ki, nem költöttek hozzá a meséhez a gyermekek.

A kultúraspecifikus elemek elidegenítő fordítása rövidtávon előnyösnek mutatkozik, egyértelműen más lehetőségeket és pozitívumokat rejt. Noha a kevesebb idegen elemet tartalmazó mesékkel szemben, ez a megközelítés egyelőre kevésbé tünik alkalmasnak az ellazult, érzelmi folyamatokat beindító mesehallgatásra, ugyanakkor mind oktatási célokra, mind a gyermekek fantáziájának élénkítésére hasznos lehet, illetve segíthet, hogy idősebb korukban, mind az irodalomban, mind életük más területein, nagyobb magabiztossággal mozoghassanak a különböző kultúrák között.

Mindezek alapján, úgy tủnik érdemes folytatni a kutatást: nagyobb mintán pontosítani az eddigi következtetéseket, illetve hosszú távon megállapítani, vajon melyik a legideálisabb kor az elidegenítő fordítás bevezetésére a gyermekek életébe. A fiatalok pozitívabb megítélése mindenképp azt mutatja, hogy jó irányba haladunk. Egy lehetséges paradigmaváltás bővíthetné gyermekirodalmi kínálatot, ami mind a szülők és pedagógusok, mind a gyerekek számára változatosabb, sokoldalúbb felhasználást és táguló világképet eredményezhetne. 


\title{
3. helyezett
}

\section{Az ördög ... lakik: elhallgatás és hozzáköltés az ifjúsági irodalom fordításában}

\author{
Rudolf Anna \\ (ELTE, Összehasonlitó irodalom- és kultúratudomány $M A$ )
}

Témavezető: Sohár Anikó (PPKE, egyetemi docens)

A problémacentrikus ifjúsági regénynek (másik nevén tabukönyvnek) a magyarországi kiadói gyakorlatban sem a rendszerváltás előtt, sem az azutáni első évtizedben nem volt hagyománya. Elsőként a kétezres évek elején az Animus kiadó kezdett a müfaj kortárs klasszikusainak programszerü megjelentetésébe.

A gyerek- és ifjúsági irodalom fordításában, érzékeny társadalmi pozíciójánál fogva, régi hagyománya van az adaptációnak, akár öntudatlan cenzúrázásnak, elhallgatásnak, hozzátoldásnak, a célnyelvi kultúrába nehezen illeszthető részletek megváltoztatásának. Kimberley Reynolds alapvetéséből kiindulva, miszerint bármely időszak gyerekkönyvkiadása magán viseli a korszak gyerekfelfogásának lenyomatát, dolgozatomban azt vizsgálom, hogy milyen témákat talált az irodalmi intézményrendszer elfogadhatatlannak ebben a húsz évvel ezelőtti időszakban az ifjúság számára. Ennek megfelelően nem magukat a témákat és azok kezelését vizsgáltam, hanem három regény teljes szövegét (Laurie Halse Anderson: Hadd mondjam el..., Anne Fine $A$ kilencedik felhön és E. L. Konigsburg Szavak nélkül) hasonlítottam össze angol eredetijével, és a kihagyásokból és betoldásokból kirajzolódó képen keresztül térképeztem fel a kimondhatatlant.

$\mathrm{Az}$ alkalmazott fordítói stratégiák tétje túlmutat az egyszeri olvasón: egy új irányzat importálásakor a fordítások feladata kialakítani a hozzá kapcsolódó múfaji és nyelvi kódokat, jelen esetben azt, hogy milyen témákról, milyen mélységben és milyen regiszterben szólhat egy ifjúsági regény. A tudatos kiadói igény ütközik tehát az öntudatlan fordításhagyománnyal.

A három regény központi témája a nemi erőszak, a mentális betegségek és öngyilkosság, illetve egy súlyos testi sértés körülményeinek felderítése. Mindhárom esetben ezt a témát is érinti a kihagyások gyakorlata, ami önmagában is meglepő. A talált eltérések részben megfeleltek az elvárhatónak - a kulturális reáliák és leíró részek maradtak ki -, de ezek az esetek töredékét jelentik. A többi, regényenként több száz változtatás néhány jól körülhatárolható téma köré csoportosul. Eltérő mértékben, de következetesen kerülik a szexualitásnak és meztelenségnek, az erőszak minden formájának, akár jogi vagy erkölcsi vonatkozásban is, illetőleg a halálnak és halandóságnak az említését. Az ezekről szóló részeket nemcsak az arról szóló regényben, hanem a többiben is jelentősen megrövidítették vagy teljesen kihagyták. Feltünők még emellett a hagyományos társadalmi és nemi szerepek megerősítései, ezek sokszor narrátori kommentárokként közvetítenek értékítéletet egyes szereplők viselkedéséről: egy kitett csecsemőt magyarul kartondobozba tettek egy kuka teteje helyett, a nem 
elég gondos anyák felelőtlenségre utaló jelzőket kapnak, az ünneplő apák sörözés helyett kávézni mennek.

Szintén elmaradnak a humoros részek: főként az Anderson-regény elbeszélőjének gyilkos iróniája, illetve a szatirikus vagy fekete humor. Egy emlékezetes, vicces epizódban egy fiú kényszerüségből lányruhába öltözik, de csak angolul, magyarul egy fiútól kéri kölcsön az iskolai egyenruháját. Jellemzők ezen felül a stilisztikai változtatások, határozószók és kötőszók betoldása, a köznyelvi regiszter ünnepélyessé emelése, a hiányos mondatok kiegészítése, az olykor modorosságig fokozódó választékosság, illetve a szleng elhagyása. Mindez arra enged következtetni, hogy nemcsak tematikusan, de nyelvhasználatban is kötött, hogy milyen lehet egy ifjúsági olvasónak szánt regény.

Mindazonáltal ezek az erősen rövidített, átdolgozott fordítások mindössze eredetijükhöz képest szelídek: a piaci kortársaikhoz képest még így is szókimondók, és a konvenció óvatos feszegetése mindenképp elévülhetetlen érdemük. Vélhetőleg az elmúlt húsz évben történt elmozdulás a normában, erre utal, hogy a sorozat maradandóbb darabjai közül több megjelent azóta felújított vagy teljesen új fordításban is.

Nekem mint a harmadik helyezett témavezetőjének külön örömet okozott, hogy mindhárom helyezett alapos szakirodalmi ismeretekkel, kifogástalan módszertannal rendelkező és a (fordítói, fordítóképző) gyakorlat számára is releváns kutatással rukkolt elő, mindhármukban megvan az a kutatói kíváncsiság, amely nem nyugszik, míg végére nem jár az őt érdeklő kérdésnek, s meggyőződésem, hogy fogunk mi még mindhármuk nevével találkozni ennek a folyóiratnak a hasábjain.

\section{Irodalom}

Cámara-Aguilera, E., Faber, P. 2015. A Children's Comparative Study of Recall, Comprehension and Motivation of One Foreign Book in Three Translation Versions. In: Roig Rechou, B.-A., Kenfel, V. R., García, L. L. (eds) Anuario de investigación en literatura infantil y juvenil. 21-38. doi: 10.15713/ins.mmj.3.

Gerloff, P. 1986. Second Language Learners' Reports on the Interpretive Process: Talk-aloud Protocols of Translation. In: House, J., Blum-Kulka, B. (eds) Interlingual and intercultural communication. Tübingen: Gunter Narr. 274-262.

Hurtado Albir, A. 2017. Researching Translation Competence by PACTE Group. Amsterdam/Philadelphia: Benjamins.

Krings, H. P. 1986. Was in den Köpfen von Übersetzern vorgeht: Eine empirische Untersuchungder Struktur des Übersetzungsprozesses an fortgeschrittenen Franzözischlernern. Tübingen: Gunter Narr.

Puurtinen, T. 2006. Translating Children's Literature: Theoretical Approaches and Empirical Studies. In: Lathey, G. (ed.) The translation of children's literature: a reader. Clevedon: Multilingual Matters. 54-64.

Séguinot, C. 1991. A Study of Student Translation Strategies. In: Tirkkonen-Condit, S. (ed.) Empirical research in translation and intercultural studies, Tübingen: Gunter Narr. 79-88. 
Séguinot, C. 1996. Some Thoughts about Think-aloud Protocols. Target Vol. 8. No. 1. 75-95.

Telci, Ü. A., Çoban, F. 2017. Examining the Contribution of the Translations of Children's Literature and Young Adult Literature to Cultural and Universal Values Education in Terms of Tranlator Decisions. The Fournal of International Lingual, Social and Educational Sciences Vol. 3. No. 1. 37-43.

Yamazaki, A. 2002. Why Change Names? On the Translation of Children's Books. Children's Literature in Education Vol. 33. No. 1. 53-62.

\section{Források}

Anderson, L. H. 2006. Hadd mondjam el... Ford. Csatári Ferenc. Budapest: Animus. Fine, A. A kilencedik felhőn. Ford. Damokos Kata. Budapest: Animus.

Konigsburg, E. L. 2005. Szavak nélkül. Ford. Rácz Péter. Budapest: Animus. 